Tomasz Jurczyk

(Uniwersytet Łódzki)

\title{
Polityka Chińskiej Republiki Ludowej ery Deng Xiaopinga wobec Tajwanu
}

Od powstania w 1949 r. Chińskiej Republiki Ludowej (ChRL) władze w Pekinie niezmiennie uznawały Tajwan za część Chin i opowiadały się za zjednoczeniem państwa chińskiego. Strategia, dzięki której miano ten cel osiągnąć, ulegała jednak zmianom, a największe $\mathrm{z}$ nich miały miejsce pod koniec lat siedemdziesiątych oraz na początku dziewięćdziesiątych $\mathrm{XX}$ w. W pierwszym wypadku nastapiło odejście od planów zbrojnego „wyzwolenia” wyspy na rzecz pokojowego zjednoczenia, w drugim zaś coraz silniej zaczęto akcentować ewentualność użycia wobec Tajwanu siły.

W latach 1978-1993 kluczową rolę w polityce chińskiej odgrywał Deng Xiaoping. Wskazany okres charakteryzował się zmniejszeniem napięcia militarnego w Cieśninie Tajwańskiej przy jednoczesnym rozbudzeniu oczekiwań dotyczących politycznego rozwiązania sporu o Tajwan. Warto jednak zastanowić się nad tym, dlaczego problem tajwański zajmował w omawianym okresie jedno $\mathrm{z}$ kluczowych miejsc $\mathrm{w}$ polityce chińskiej oraz do jakich celów był wykorzystywany. Dzięki temu łatwiejsze będzie zrozumienie zachowania przywódców chińskich wobec Tajwanu także na początku XXI w., gdyż stanowisko Pekinu w tym względzie zostało wypracowane właśnie przez Deng Xiaopinga.

Istotne dla omawianego zagadnienia jest w pierwszej kolejności przedstawienie miejsca Tajwanu w chińskiej tożsamości narodowej, następnie omówiona zostanie rola kwestii tajwańskiej w legitymizowaniu władzy Komunistycznej Partii Chin (KPCh), jej znaczenie dla bezpieczeństwa narodowego, problematyka uczuć narodowych, polityki wewnętrznej ChRL oraz argumenty dotyczące strategicznego znaczenia wyspy. Artykuł zakończy krótki opis sytuacji po 1989 r., kiedy to kształtowała się nowa, pozimnowojenna polityka chińska wobec Tajwanu.

\section{Tajwan a chińska tożsamość narodowa}

Nowoczesna chińska tożsamość narodowa, czyli poczucie odrębności wobec innych narodów, zaczęła się kształtować dopiero w drugiej połowie XIX w. w wyniku kryzysu jaki przeżywało wtedy Cesarstwo Chińskie rządzone przez 
mandżurską dynastię Qing ${ }^{1}$. Kontakt ze stojącymi na wyższym poziomie rozwoju technicznego państwami zachodnimi spowodował, że musiało ulec weryfikacji przekonanie o wyższości kultury chińskiej nad wszystkimi pozostałymi. Przewartościowanie to stało się niezmiernie istotne także z politycznego punktu widzenia, gdyż to właśnie kultura chińska była jednym z najważniejszych czynników spajających imperium ${ }^{2}$. Sytuację zaogniał dodatkowo fakt, iż dziewiętnastowieczne kontakty Państwa Środka z państwami europejskimi, Stanami Zjednoczonymi, a w późniejszym okresie również Japonią były zdominowane przez wojny i poniżające dla Chin warunki pokoju.

Dopiero w obliczu kryzysu elity zaczęły myśleć o państwie w kategoriach politycznych i terytorialnych, a nie kulturowych ${ }^{3}$. Jednym z kluczowych zagadnień stało się wtedy pojęcie suwerenności państwowej. Szczególnie doświadczone przez imperializm Chiny zaczęły podkreślać bowiem zasadę równości podmiotów prawa międzynarodowego (obcą tradycyjnej chińskiej myśli politycznej, w której to Chiny dominują nad wszystkimi pozostałymi podmiotami) oraz zakaz ingerencji w wewnętrzne sprawy poszczególnych państw ${ }^{4}$. Były wtedy jednak zbyt słabe, aby móc w pełni skorzystać z wymienionych praw, czego efektem było zdominowanie dwudziestowiecznej polityki chińskiej przez poszukiwania drogi do odrodzenia narodowego.

Chińskie elity nigdy nie odrzuciły głęboko zakorzenionego tradycyjnego sinocentryzmu. Przejawiał się on m.in. w przekonaniu, że Chińczycy powinni być rządzeni przez Chińczyków ${ }^{5}$. Co więcej, uważano również, iż Chińczycy znajdujący się pod obcymi rządami tracą swoją chińskość. Było to jedną z przyczyn nie wysuwania przed 1942 r. żądań powrotu Tajwanu do Chin ${ }^{6}$, a także polityki przywracania chińskości, zainicjowanej przez rząd kuomintangowski po odzyskaniu wyspy w $1945 \mathrm{r}$.

$\mathrm{Na}$ początku lat dziewięćdziesiątych $\mathrm{XX}$ w. pojawił się nowy czynnik. $\mathrm{W}$ zmienionych pozimnowojennych realiach cechujący dekadę lat osiemdzie-

\footnotetext{
${ }^{1}$ Pojęcia takie jak „tożsamość narodowa” czy „nacjonalizm” nadal wywołują kontrowersje i są przedmiotem ożywionej debaty wśród przedstawicieli nauk społecznych. Wiele wątpliwości pojawia się również przy stosowaniu ich w odniesieniu do Chin, przede wszystkim zaś początków nowoczesnego narodu chińskiego, jego charakteru oraz konsekwencji wydarzeń historycznych, związanych z jego powstaniem. Szerzej o debacie na temat chińskiej tożsamości narodowej patrz: S. Z h a o, A Nation-State by Construction. Dynamics of Modern Chinese Nationalism, Stanford 2004, s. 12-29.

${ }^{2}$ Stąd też Chinami mogły rządzić obce etnicznie dynastie (np. mandżurska dynastia Qing), o ile zaakceptowały dominującą rolę kultury chińskiej w państwie.

${ }^{3}$ S. Z h a o, op. cit., s. 37-38.

${ }^{4}$ Ibidem, s. 49.

${ }^{5}$ R. C. B u s h, Untying the Knot. Making Peace in the Taiwan Strait, Washington 2005, s. 189 .

${ }^{6}$ F. H s i a o, L. S u 11 i v a n, The Chinese Communist Party and the Status of Taiwan 19281943, „Pacific Affairs” 1979, Vol. 52, Iss. 3, s. 446-467.
} 
siątych entuzjazm intelektualistów chińskich wobec Zachodu został zastąpiony głęboką podejrzliwością, szczególnie w stosunku do Stanów Zjednoczonych? ${ }^{7}$. Momentem przełomowym w tym względzie było wprowadzenie przez państwa zachodnie sankcji gospodarczych po stłumieniu przez władze chińskie protestów wiosną 1989 r. Paradoksalnie, nawet osoby nie popierające rządu odebrały sankcje jako pogwałcenie praw Chińczyków jako narodu. Zaczęto wtedy mówić o blokowaniu przez Zachód wzrostu znaczenia Chin na arenie międzynarodowej.

Jak w tym kontekście przedstawia się kwestia tajwańska? Przede wszystkim w zbiorowej świadomości Chińczyków Tajwan był jednym z symboli poniżenia Chin. Rację ma przy tym Richard Bush, który twierdzi, że współczesne podkreślanie w Chinach statusu ofiary jest zjawiskiem stosunkowo nowym, bowiem w czasie rewolucji kulturalnej „marksizm-leninizm przekształcił nacjonalizm w antyimperializm, a wspomnienia chińskiej przeszłości podkreślały zwycięstwo Chińczyków nad zagraniczną agresją i eksploatacją"”. Po drugie, w przekonaniu wielu obywateli ChRL, Tajwan jako terytorium zamieszkane w zdecydowanej większości przez ludność etnicznie i kulturowo chińską powinien być, zgodnie $\mathrm{z}$ tradycyjnym sinocentryzmem, rządzony przez władze chińskie ${ }^{10}$. Po trzecie, Tajwan stanowi ważny element stosunków chińsko-amerykańskich. W tym kontekście wysuwane są też zarzuty wspierania sił dążących do formalnej niepodległości Tajwanu przez zagranicę.

\section{Tajwan a legitymizacja władzy ChRL}

Jak już wspomniano, jednym z dominujących elementów dwudziestowiecznej polityki chińskiej było dążenie do odrodzenia Chin. Na początku ubiegłego stulecia czołowy chiński rewolucjonista, Sun Yat-sen, stwierdził, że Chińczycy jako naród przypominają zaledwie „luźny kopiec piasku” (yipan sansha), gdyż w większości identyfikują się nie z państwem narodowym, ale z lokalną społecznością opartą na więzach feudalnych. W związku z tym najpierw należało podjąć się misji stworzenia nowoczesnego narodu chińskiego, który przywróciłby Chinom miejsce należne im w świecie. Odpowiedzią założonej przez Sun Yat-sena Partii Narodowej (Kuomintangu) był program budowy tożsamości narodowej w oparciu o elity. W kwestii praktycznej realizacji powyższych

${ }^{7}$ S. Z h a o, op. cit., s. 10.

${ }^{8}$ Ibidem, s. 25.

${ }^{9}$ R. C. B u s h, op. cit., s. 192.

${ }^{10} \mathrm{~W}$ przeciwieństwie do sytuacji sprzed 1942 r., Tajwan w chińskiej świadomości zbiorowej jest obecnie uważany za chiński pod względem kulturowym. Wpływ na taką ocenę miało niewątpliwie przybycie na wyspę w 1949 r. wielu uchodźców z kontynentu oraz polityka rządu kuomintangowskiego odwołująca się do ogólnochińskiej tożsamości narodowej. 
zamierzeń, początkowo skłaniający się w stronę demokracji parlamentarnej Sun ostatecznie zdecydował się na dyktaturę (w jego założeniach przejściowa) jednej partii - Kuomintangu. Abstrahując od przyczyn o wymiarze międzynarodowym $^{11}$, decyzja ta wynikała również z przeświadczenia, że Chińczycy nie są w wystarczającym stopniu zaznajomieni z praktyką funkcjonowania demokracji i nowoczesnego państwa ${ }^{12}$.

W czasie wojny z Japonią Komunistyczna Partia Chin rywalizowała z Partią Narodową o to, która z nich jest prawdziwie patriotyczna. Już od czasu zajęcia Mandżurii przez wojska japońskie w $1931 \mathrm{r}$. KPCh uczyniła bowiem z kwestii utrzymania integralności terytorialnej jeden $\mathrm{z}$ najważniejszych czynników legitymizujących własne dążenia do władzy. Służyło temu skontrastowanie deklaracji wojny z Japonią z reakcją Czang Kaj-szeka, którego komuniści oskarżyli wtedy o sprzedanie Chin (przed podjęciem walki z Japończykami chciał on bowiem najpierw rozprawić się z komunistami) ${ }^{13}$. Należy przy tym podkreślić, że KPCh dawała również inną odpowiedź na pytanie o to, kto ma przewodzić budowaniu nowoczesnego państwa i narodu. Nie były to już - jak w przypadku Kuomintangu - elity, lecz masy. Działanie takie w dużej mierze zadecydowało o zwycięstwie komunistów, którzy dzięki poparciu na wsi oraz silnej pozycji wśród inteligencji odnieśli sukces w wojnie domowej.

Jak więc widać, opieranie legitymizacji władzy jednej partii na realizowaniu przez nią misji ocalenia narodowego jest częścią dwudziestowiecznej chińskiej tradycji politycznej, wykraczającej poza historię Chińskiej Republiki Ludowej. Choć nacjonalizm był już przez krótki okres (tuż po powstaniu ChRL, w 1949 r.) wykorzystywany do legitymizowania władzy, to od czasu reform stał się on kluczową podporą systemu ${ }^{14}$. Po tragicznym okresie rewolucji kulturalnej ideologia komunistyczna przestała już kierować życiem milionów obywateli ChRL. Na nowo odkryto nacjonalizm, co ,zbiegło się w czasie ze wzrostem znaczenia pragmatyzmu jako dominującego sposobu myślenia tak obywateli chińskich, jak i ich przywódców. [W efekcie] Chińczycy użyją każdego sposobu, aby się wzbogacić, a przywódcy Chin przyjmą każdy system wartości, który pomoże im w walce o władzę i bogactwo" ${ }^{15}$.

Impulsem do zmian była śmierć Mao Zedonga w roku 1976 i przejęcie władzy przez pragmatycznego Deng Xiaopinga. Podczas III plenum Komitetu

${ }^{11}$ Sun Yat-sen zdecydował się szukać wzorców w Moskwie po tym jak rozczarował się postawą państw zachodnich oraz Japonii. Przez dziesięć lat zabiegał on bowiem o pomoc gospodarczą dla nowopowstałej republiki, spotykając się przy tym nie tylko z obojętnością, ale również z narastającymi roszczeniami wobec Chin (głównie ze strony imperialistycznej Japonii).

${ }^{12} \mathrm{Ch} . \mathrm{H} \mathrm{u} \mathrm{g}$ h e s, Taiwan and Chinese nationalism. National identity and status in international society, London-New York 1997, s. 7-8.

${ }^{13}$ Ibidem, s. 13.

${ }^{14}$ S. Z h a o, op. cit., s. 214.

${ }^{15}$ Ibidem, s. 214. 
Centralnego KPCh w grudniu 1978 r. przyjęto program tzw. „czterech modernizacji" (w przemyśle, rolnictwie, w obszarze obrony narodowej oraz nauki i techniki), postanowiono też otworzyć kraj na kontakty z zagranicą. Realizacja tych zamierzeń wymagała jednak przyjaznego Chinom otoczenia międzynarodowego, które dodatkowo mogło być źródłem kapitału i nowych technologii ${ }^{16}$. W tym kontekście podjęto decyzję o zmianie polityki tajwańskiej ChRL na bardziej pokojową, co było jak najbardziej zrozumiałe, szczególnie, jeżeli weźmie się pod uwagę możliwość wykorzystania tajwańskiego potencjału gospodarczego w procesie reformowania Chin $^{17}$.

Inne podejście do Tajwanu nie byłoby jednak możliwe, gdyby nie zmiana sytuacji międzynarodowej. Na przestrzeni całej dekady lat siedemdziesiątych XX w. Chiny wzmacniały swoją pozycję na arenie międzynarodowej kosztem Tajwanu. Najważniejszymi wydarzeniami w tym względzie było zajęcie miejsca Chin w ONZ przez rząd Chińskiej Republiki Ludowej w 1971 r., a także zbliżenie chińsko-amerykańskie, którego wyrazem była wizyta prezydenta USA, Richarda Nixona, w Chinach w 1972 r. oraz nawiązanie stosunków dyplomatycznych pomiędzy Chinami i Stanami Zjednoczonymi w 1979 r. ${ }^{18} \mathrm{~W}$ efekcie Republika Chińska (RCh) z jednej strony straciła miejsce w organizacjach międzynarodowych, z drugiej - uznanie ze strony większości uprzemysłowionych państw świata. Na dodatek wszystkie państwa, które nawiązywały stosunki dyplomatyczne z Pekinem musiały uznać Tajwan za część Chińskiej Republiki Ludowej. ChRL nie mogła jednak wykorzystać tej sytuacji, aby narzucić Tajwanowi rozwiązanie siłowe, gdyż z jednej strony nie dysponowała odpowiednim zapleczem wojskowym, $\mathrm{z}$ drugiej zaś groziło to przerwaniem dopiero co zawiązanej współpracy ze Stanami Zjednoczonymi.

Sygnałem rewizji polityki wobec Tajwanu stała się „Odezwa do rodaków na Tajwanie”, wydana 1 stycznia 1979 r. przez Stały Komitet Ogólnochińskiego

${ }^{16}$ E. H a 1 i ż a k, Polityka zagraniczna ChRL: uwarunkowania decyzyjne $i$ wizje rzeczywistości międzynarodowej, [w:] Chiny. Przemiany państwa i społeczeństwa w okresie reform 19782000 , red. K. Tomala, Warszawa 2001, s. 223-224.

${ }^{17}$ Działanie takie było przy tym w pełni zbieżne z generalnymi założeniami chińskiej polityki zagranicznej okresu Deng Xiaopinga. Opierały się one na przeświadczeniu, że otoczenie międzynarodowe jest w większym stopniu źródłem środków potrzebnych do modernizacji kraju niż zagrożeniem, a utrzymanie pokoju i rozwój są głównymi trendami w stosunkach międzynarodowych. Deng rozszerzył przy tym chińskie rozumienie bezpieczeństwa narodowego z problematyki wojskowej i politycznej, także na kwestie ekonomiczne, społeczne, naukowe i techniczne. Za: X. W u, China Security Practice of a Modernizing and Ascending Power, [w:] Asian Security Practice. Material and Ideational Influences, Stanford 1998, red. M. Alagappa, s. 122-124.

${ }^{18}$ Dla Pekinu, w kontekście kwestii tajwańskiej, zbliżenie z Waszyngtonem było szczególnie ważne gdyż od 1949 r. uważano, że to właśnie amerykańskie zaangażowanie na Tajwanie jest główną przeszkodą dla zjednoczenia; J. Z h a n, Ending the Chinese Civil War. Power, Commerce, and Conciliation between Beijing and Taipei, New York 1993, s. 31. 
Zgromadzenia Przedstawicieli Ludowych (OZPL). Co prawda, potwierdzono w niej stanowisko Pekinu, które odmawiało rządowi Republiki Chińskiej prawa do reprezentowania całych Chin, z drugiej jednak strony nadzieje na przyszłość pokładano nie tylko w mieszkańcach Tajwanu, do których odezwa była bezpośrednio skierowana, lecz także we władzach tajwańskich, które „,zawsze stały na stanowisku jedności Chin i sprzeciwiały się niepodległości Tajwanu” i miały być partnerem dla Pekinu w rozmowach dotyczących zaniechania wrogości w stosunkach wzajemnych ${ }^{19}$.

Najważniejszym elementem „Odezwy...” była jednak propozycja pokojowego zjednoczenia. Stwierdzono, że przywódcy chińscy wezmą pod uwagę obowiązujące realia oraz uszanują status quo na Tajwanie, a rozwiązania zastosowane przez nich w celu zjednoczenia nie spowodują u mieszkańców Tajwanu żadnych strat. Jak widać propozycja ta była dość ogólna, stanowiła jednak przełom w zakresie przewidywanych metod (pokojowych) i zapowiedzi wzięcia pod uwagę warunków na wyspie innych w porównaniu do kontynentu. Skonkretyzowaniem zapowiedzi z „Odezwy...” stała się propozycja zjednoczenia na zasadzie ,jeden kraj - dwa systemy”, co miało miejsce w pierwszej połowie lat osiemdziesiątych. Warto w tym miejscu zaznaczyć, że powyższa linia polityczna ma swoje źródła we wcześniejszych koncepcjach pokojowego rozwiązania konfliktu, jakie pojawiły się jeszcze w latach pięćdziesiątych ${ }^{20}$.

Analizująć wskazaną odezwę należy również zwrócić uwagę na fakt, iż zmiany drugiej połowy lat siedemdziesiątych znalazły swoje odzwierciedlenie także w języku, w jakim ją napisano. Użycie terminu „,władze tajwańskie” w celu umniejszenia statusu rządu RCh - w przeciwieństwie do wcześniej używanej „kliki Czang Kaj-szeka” (Jiang bang) miało neutralny wydźwięk. Zaprzestano także stosowania agresywnego, zakładającego użycie siły zbrojnej określenia „wyzwolenie” na rzecz ,zjednoczenia”, które w kontekście całego dokumentu miało odbyć się w sposób pokojowy ${ }^{21}$.

Bardzo ważna dla określenia miejsca Tajwanu w polityce ChRL jest jednakże analiza wypowiedzi Deng Xiaopinga z 1980 r. o celach Chin w latach osiemdziesiątych. Pozwala ona bowiem na zrozumienie, w jaki sposób kwestia tajwańska była wykorzystywana w wewnętrznej polityce chińskiej. Powrót Tajwanu do macierzy został wtedy wymieniony obok reform ekonomicznych i sprzeciwiania się hegemonii w stosunkach międzynarodowych. Takie powią-

${ }^{19}$ N. P. C. Standing Committee Message to Compatriots in Taiwan, http://www.fmprc.gov. cn/eng/ljzg/3568/t17790.htm.

${ }^{20}$ M. D. S w a i n e, Chinese Decision-Making Regarding Taiwan, 1979-2000, [w:] The Making of Chinese Foreign and Security Policy in the Era of Reform, red. D. M. Lampton, Stanford 2001, s. 311.

${ }^{21}$ Niedługo potem analogiczna zmiana terminologii miała również miejsce na Tajwanie, m.in. od 1982 r. zaczęto używać terminu „chińskie władze komunistyczne” (zhonggong dangju) zamiast „komunistyczni bandyci” (gongfei). 
zanie tych trzech kwestii było działaniem bardzo znaczącym, gdyż prowadziło do rozumowania, w myśl którego rozwój ekonomiczny jest zaledwie warunkiem osiagnięcia wyższych celów polityki zagranicznej i zjednoczeniowej. Zjednoczenie narodowe i sprzeciw wobec hegemonii na arenie międzynarodowej stały się wyznacznikiem sukcesu reform. Podawanie w wątpliwość polityki ekonomicznej było więc zakazane nie z powodu odstępstw od dogmatów komunistycznych, lecz dlatego, iż osłabiało pozycję Chin wobec świata zewnętrznego i uniemożliwiało zjednoczenie. Sprzeciw wobec reform ekonomicznych byłby czynem nie-patriotycznym ${ }^{22}$.

Na XII Zjeździe KPCh we wrześniu 1982 r. nie eksponowano już jednak tak wyraźnie kwestii powrotu Tajwanu. Mówiono już nie o ,powrocie Tajwanu do macierzy, będącym realizacją idei zjednoczenia ojczyzny" (shixian Taiwan huigui zuguo, shixian zuguo tongyi), ale o „osiagnięciu realizacji idei zjednoczenia ojczyzny, włączając w to Tajwan" (zhengqu shixian baokuo Taiwan zai nei de zuguo tongyi). Wynikało to, $\mathrm{z}$ jednej strony, ze wzrostu pewności siebie liderów co do programu reform ekonomicznych, z drugiej zaś - kontynuacji sprzedaży przez USA broni na Tajwan, nawet po podpisaniu 17 kwietnia $1982 \mathrm{r}$. komunikatu w sprawie zaprzestania tych działań (była to niewątpliwie porażka Pekinu). W zamian za to $\mathrm{w}$ kwestii zjednoczenia akcent został przesunięty na kwestię powrotu Hongkongu, co było w tamtym okresie bardziej realistycznym celem $^{23}$. Przykład ten świadczy o tym, że kwestia przyłączenia Tajwanu do pewnego stopnia była wykorzystywana instrumentalnie i stanowiła element wewnątrzpartyjnej walki o władzę ${ }^{24}$.

Pewną rolę odgrywały też czynniki osobiste. Dengowi zależało na przyłączeniu Tajwanu również dlatego, iż chciał być zapamiętany jako ten, który doprowadził do ponownego zjednoczenia Chin. Uważał przy tym, że po śmierci starszej generacji przywódców tajwańskich sytuacja może ulec dalszemu skomplikowaniu. Pomimo doświadczeń z okresu wojny domowej politycy chińscy czuli się bowiem bardziej komfortowo, kontaktując się ze starymi działaczami kuomintangowskimi, gdyż mieli z nimi osobistą styczność we wcześniejszym okresie, a także posiadali wspólne poczucie przynależności narodowej. Młodsi politycy tajwańscy, choć może bardziej pragmatyczni i skłonni do rozmów, byli

${ }^{22} \mathrm{Ch} . \mathrm{H}$ u g h e s, Chinese Nationalism in the Global Era, London-New York 2006, s. 15.

${ }^{23}$ Ibidem, s. 24-26.

${ }^{24}$ Warto w tym miejscu przyjrzeć się również zapisom konstytucji, dotyczącym Tajwanu. Pierwsze odniesienie do Tajwanu (,wyzwolenie”) znajduje się dopiero w preambule do trzeciej konstytucji ChRL z 1978 r. czyli przypada na okres, gdy Hua Guofeng starał się utrzymać przy władzy, próbując połączyć maoizm z reformami ekonomicznymi, przy masowym niezadowoleniu z rządów KPCh. W konstytucji z 1982 r. doprowadzenie do ponownego zjednoczenia Tajwanu z macierzą jest obowiązkiem każdego Chińczyka, wpisuje się też w historię KPCh jako partii prowadzącej do odrodzenia narodowego. Za: Ch. Hu g h e s, op. cit., s. 15. 
nieznani w Pekinie, wzbudzali przy tym niepokój swoimi poglądami na przyszłość Tajwanu jako części Chin ${ }^{25}$.

Należy jednak podkreślić, iż w okresie reform panował wewnątrzpartyjny konsensus dotyczący podstaw polityki wobec Tajwanu, a okresowo pojawiające się różnice opinii odnosiły się tylko do szczegółowych wytycznych i taktyki ${ }^{26}$. Późniejsze zmiany w polityce ChRL wobec Tajwanu były modyfikacjami albo odpowiedzią na zagrożenie realizacji podstawowej strategii Denga ${ }^{27}$. Wyrażała się ona przede wszystkim dążeniem do zjednoczenia w myśl wspomnianej już formuły: ,jeden kraj - dwa systemy" ${ }^{\text {"28 }}$. Zakładała ona funkcjonowanie Tajwanu w ramach ChRL jako specjalnego regionu autonomicznego, który miał cieszyć się daleko idącą samodzielnością. Pekin nie ingerowałby w sprawy wewnętrzne (w szczególności gwarantowano zachowanie istniejącego systemu ekonomiczno-społecznego), pozostawiłby niezależne sądownictwo oraz armię. Zachętą dla Tajwańczyków miały być stanowiska w rządzie centralnym oraz gwarancje swobody prowadzenia interesów i osiedlania się w Chinach kontynentalnych. Takie rozwiązanie sprawiłoby jednak, iż rząd w Tajpej byłby zaledwie rządem lokalnym, podporządkowanym władzom w Pekinie, zanegowana byłaby więc jego władza suwerenna. Podejście to było również widoczne w stanowisku chińskim co do samego trybu prowadzenia negocjacji zjednoczeniowych - miały one przebiegać pomiędzy KPCh i Kuomintangiem (a nie rządami).

\section{Tajwan a bezpieczeństwo narodowe ChRL}

Strategiczne położenie wyspy, w bliskiej odległości od wybrzeży Chin, pomiędzy Filipinami i Japonią, sprawia, iż Tajwan jest jednocześnie „bramą do Chin” oraz „chińskim wyjściem na Pacyfik”. Czang Kaj-szek w swojej książce Przeznaczenie Chin (Zhongguo zhi mingyun) nazwał Tajwan jedną $\mathrm{z}$ fortec koniecznych dla zapewnienia Chinom bezpieczeństwa i obrony. Pamiętając wyprowadzony z Tajwanu japoński atak na Filipiny, również prezydent Stanów Zjednoczonych Franklin D. Roosevelt uważał, iż terytorium to powinno być

${ }^{25} \mathrm{~S} . \mathrm{Z} \mathrm{h}$ a o, Economic Interdependence and Political Divergence. A Background Analysis of the Taiwan Strait Crisis, [w:] Across the Taiwan Strait. Mainland China, Taiwan, and the 19951996 Crisis, red. S. Zhao, New York-London 1999, s. 33.

${ }^{26}$ Y. C h u, Power Transition and the Making of Beijing's Policy towards Taiwan, „China Quarterly", December 2003, s. 962.

${ }^{27}$ M. D. S w a i n e, op. cit., s. 312.

${ }^{28}$ Sam termin ,,jeden kraj - dwa systemy” został po raz pierwszy użyty przez Deng Xiaopinga w 1982 r. Założenia tego rozwiązania zostały jednak przestawione po raz pierwszy 30 września 1981 r. przez Ye Jianyinga, przewodniczącego Stałego Komitetu OZPL, jako tzw. dziewięć punktów. Dalszego rozwinięcie koncepcji ,jeden kraj - dwa systemy” dokonał Deng Xiaoping w kilku swoich wypowiedziach z pierwszej połowy lat osiemdziesiątych. 
w posiadaniu sił przyjaznych USA. Stąd w czasach zimnej wojny Tajwan nazywany był z kolei przez Amerykanów „niezatapialnym lotniskowcem”29.

Jak jednak przedstawiała się kwestia tajwańska w omawianym okresie? Do najważniejszych celów polityki bezpieczeństwa narodowego ChRL należało utrzymanie niezależności i integralności terytorialnej oraz zapewnienie przetrwania istniejącego reżimu. Kluczem do realizacji wymienionych założeń były przede wszystkim rozwój gospodarczy, stabilne otoczenie międzynarodowe oraz poprawne relacje bilateralne $\mathrm{z}$ innymi państwami ${ }^{30}$. Główną ideą przyświecającą przywódcom chińskim od początku istnienia ChRL było zaś uczynienie z Chin mocarstwa $^{31}$.

W każdym z wymienionych powyżej elementów występował silny czynnik tajwański. W odniesieniu do kwestii integralności terytorialnej był on szczególnie istotny nie tylko w stosunku do samego Tajwanu, lecz także części składowych ChRL (Xinjiang, Tybet czy Mongolia Wewnętrzna). Jeżeli bowiem Pekin uznałby władze w Tajpej za równe sobie (a nie za podległe sobie władze prowincji) lub dopuścił do formalnego oddzielenia się Tajwanu od Chin, przyznałby on tym samym prawo do decydowania o swojej przyszłości także innym obszarom lub narodom wchodzącym w skład państwa chińskiego. W efekcie wspomniane tendencje separatystyczne części Chin mogłyby pójść tą samą droga, co Tajwan.

Poza wspomnianą już rolą kwestii tajwańskiej w legitymizowaniu władzy KPCh, ewentualny konflikt zbrojny z Tajwanem również mógłby zagrozić władzom w Pekinie. Doprowadziłby on przede wszystkim do destabilizacji otoczenia międzynarodowego, a nawet mógłby skutkować wojną ze Stanami Zjednoczonymi. Z pewnością ucierpiałaby na tym również gospodarka i co za tym idzie pojawiłaby się groźba destabilizacji społecznej w samych Chinach, której władze za wszelką cenę chciały uniknąć.

Na początku lat dziewięćdziesiątych wzrosło też znaczenie Tajwanu z punktu widzenia interesów Chińskiej Armii Ludowo-Wyzwoleńczej (ChAL-W; początki takiego myślenia były widoczne już w latach osiemdziesiątych). Wyłączając bowiem opisane zagadnienia związane z obroną jedności państwowej, umiejętne rozgrywanie przez wojsko karty tajwańskiej pozwalało na realizację własnych zamierzeń w trzech obszarach: utrzymania swojej pozycji

${ }^{29}$ Chińskiego zainteresowania Tajwanem w tym aspekcie można dopatrywać się nawet w dużo wcześniejszych działaniach dynastii Qing. Patrz: E. J. Te ng, Taiwan's Imagined Geography. Chinese Colonial Travel Writing and Pictures, 1683-1895, Cambridge-London 2004.

${ }^{30} \mathrm{~B}$. W u, The Chinese Security Concept and its Historical Evolution, ,Journal of Contemporary China" 2001, Vol. 10 (27), s. 278-279.

${ }^{31}$ X. W u, China Security Practice of a Modernizing and Ascending Power, [w:] Asian Security Practice. Material and Ideational Influences, ed. M. Alagappa, Stanford 1998, s. 123. 
w polityce, modernizacji oraz zwiększenia nakładów budżetowych na obronę ${ }^{32}$. W toku reform rozpoczętych w Chinach po 1978 r. społeczna i polityczna pozycja wojska ulegała bowiem stopniowemu obniżeniu w porównaniu do wcześniejszego okresu. Nakreślenie realnej wizji konfliktu o Tajwan mogło, zatem zwrócić uwagę cywilnych elit rządzących na potrzeby armii, dając jednocześnie wojskowym większy wpływ na sytuację w państwie.

Dodatkowo, w ramach samej ChAL-W, przodującym (oraz mogącym najwięcej zyskać ${ }^{33}$ ) rodzajem sił zbrojnych, uczestniczących w procesie formułowania polityki wobec Tajwanu $\mathrm{w}$ pierwszej połowie lat dziewięćdziesiątych stała się marynarka wojenna ${ }^{34}$. W jej interesie leżała bowiem zmiana strategii obronnej Chin na taką, która w większym stopniu uwzględniałaby obronę morskich interesów ChRL. Tajwan nadawał się idealnie jako obiekt działań marynarki, gdyż ewentualne użycie środków wojskowych w celu zjednoczenia wymagałoby użycia znacznych sił morskich, tak do przeprowadzenia samej inwazji, jak i unieszkodliwienia prawdopodobnego amerykańskiego wsparcia dla Tajwanu. Nowoczesna marynarka wojenna dawałaby przy tym szanse zastosowania np. blokady morskiej, dzięki której bez rozwijania konfliktu na całą skalę Pekin mógłby zmusić Tajwańczyków do negocjacji zjednoczeniowych na swoich warunkach.

\section{Przed kolejną zmianą}

W latach 1989-1992 (w dużej mierze kluczowych dla transformacji systemowej Tajwanu) wewnętrzna atmosfera polityczna w ChRL nie sprzyjała wypracowaniu całościowej koncepcji nowej polityki wobec Tajwanu. W tym czasie chińskie elity władzy bardziej zaprzątała kwestia przywrócenia równowagi po wydarzeniach na placu Tian'anmen oraz kolejny etap reform ekonomicznych Deng Xiaopinga. Poza tym pogarszający się stan zdrowia Denga ograniczał jego zainteresowanie mniej pilnymi sprawami, a pozycja wyznaczonego na jego następcę Jiang Zemina była jeszcze zbyt słaba, aby mógł on dokonać korekty polityki wobec Tajwanu ${ }^{35}$.

32 J. B i, The Role of the Military in the PRC Tajwan Policymaking: a case study of the Tajwan Strait crisis of 1995-1996, „Journal of Contemporary China” 2000, Vol. 11(32), s. 548.

${ }^{33}$ Od powstania ChRL przywiązywano zawsze wagę do wojsk lądowych, marynarka zajmowała miejsce drugorzędne. Wynikało to ze strategii tzw. wojny ludowej Mao Zedonga (wróg miał zostać pokonany przez armię prowadzącą działania partyzanckie w głębi Chin).

${ }^{34}$ Niewątpliwie przyczynił się do tego również fakt, że w 1992 r. członkiem Komitetu Stałego Biura Politycznego KC KPCh oraz pierwszym wiceprzewodniczącym Centralnej Komisji Wojskowej został były dowódca marynarki, admirał Liu Huaqing (od lat osiemdziesiątych główny orędownik modernizacji marynarki wojennej, który za cel stawiał utworzenie w XXI w. chińskiej floty oceanicznej).

${ }^{35}$ M. D. S w a i n e, op. cit., s. 317. 
Dopiero w latach 1992-1993 w bardziej widoczny sposób ukształtowały się trzy podejścia w odniesieniu do wyspy. Pierwsze z nich zakładało przyspieszenie procesu zjednoczenia poprzez ścisłą izolację międzynarodową Tajwanu, połączoną ze zwiększeniem presji (również wojskowej) na rząd w Tajpej, aby ten przystapił do rozmów. Drugie przewidywało fazowość procesu zjednoczenia, które poprzedzić miało zawarcie porozumienia pokojowego. W tym wypadku zamierzano osiągnąć cel poprzez połączenie zwiększonej presji wywieranej na Tajwan z zachętami. Generalnie można stwierdzić, że pierwsze ze wspomnianych rozwiązań cieszyło się poparciem kręgów wojskowych oraz niewielkiej części cywilów, drugie zaś było bliższe cywilnym ekspertom i elitom władzy. Trzecie podejście, mające minimalne poparcie aparatu władzy, zakładało postawę wyczekującą, której celem miało być jedynie zapobieżenie ogłoszeniu przez Tajwan formalnej niepodległości ${ }^{36}$.

Istotne zmiany przyniósł dopiero rok 1993, w którym Jiang stanął na czele prowadzonej dotąd przez przewodniczącego ChRL Yang Shangkuna Grupy Kierowniczej ds. Tajwanu (Dui Tai Gongzuo Lingdao Xiaozu) i dokonał jej restrukturyzacji, czyniąc z niej centrum podejmowania decyzji w kwestii tajwańskiej. Wtedy też Jiang postanowił zmienić dotychczasowe rozważania specjalistów na temat Tajwanu w skoordynowane działania, mające na celu wypracowanie nowej polityki tajwańskiej ChRL. Z punktu widzenia następcy Deng Xiaopinga kwestia tajwańska była ważna oraz użyteczna, także z punktu widzenia jego celów osobistych, gdyż dawała doskonałą szansę ugruntowania pozycji w partii oraz wobec wojska.

Należy w tym miejscu zauważyć, że przejęcie pełni władzy w państwie przez Jiang Zemina wywołało też daleko idące zmiany w systemie podejmowania decyzji wobec Tajwanu. Przede wszystkim coraz większą rolę zaczęła odgrywać biurokracja. Wynikało to zarówno ze zmian dokonujących się w całym państwie (Jiang nie miał takiej charyzmy jak jego poprzednicy, rządzenie Chinami stawało się coraz bardziej kolektywne), jak i ze złożonego charakteru relacji nad Cieśniną Tajwańską od początku lat dziewięćdziesiątych (były trudne do ogarnięcia przez jedną osobę). W efekcie, choć Jiang sprawował pełną kontrolę nad wszystkimi instytucjami, proces decyzyjny wydłużył się, a polityka tajwańska ChRL stała się „bardziej niezdecydowana, a nawet mało elastyczna" ${ }^{37}$. Dodatkowo w większym stopniu uwzględniano też interesy lokalne takich ośrodków, jak np. Szanghaj ${ }^{38}$.

${ }^{36}$ Ibidem, s. 316-317.

${ }^{37}$ B. Y u, Structure and Process Behind Beijing's Policy Towards Taiwan, [w:] Peace and Security Across the Taiwan Strait, red. S. Tsang, New York 2004, s. 26.

${ }^{38}$ Zwiększenie wpływów szanghajskich przy podejmowaniu decyzji dotyczących polityki tajwańskiej ChRL (to samo odnosi się też do polityki zagranicznej) wynikało także z faktu, iż Jiang Zemin był w Pekinie „osobą z zewnątrz” i poprzez nowe ośrodki analityczne w Szanghaju chciał uzyskać pełniejszy obraz sytuacji. Poza tym Szanghaj (czy prowincja Fujian) miały dużo 
Podsumowując dotychczasowe rozważania należy stwierdzić, że problem tajwański jest głęboko zakorzeniony w doświadczeniach historycznych i politycznych Chin, również tych nie związanych bezpośrednio z samą wyspa. Tajwan (w kontekście odrodzenia nacjonalizmu chińskiego) odgrywał w czasie rządów Deng Xiaopinga ważną rolę w legitymizowaniu władzy KPCh. Wpisuje się to w chińską tradycję polityczną, przede wszystkim jednak w bezpośredni sposób dotyka takich kwestii, jak integralność terytorialna, bezpieczeństwo narodowe, stabilność gospodarcza i społeczna - wszystkie one były kluczowe dla utrzymania rządów komunistycznych oraz przeprowadzenia reform. Armia również starała się wykorzystać kwestię tajwańską do realizacji własnych celów, głównie zwiększenia wpływów po okresie osłabienia swojej pozycji w czasie reform ekonomicznych. Bardzo ważnym czynnikiem warunkującym politykę Pekinu wobec Tajwanu była także sytuacja międzynarodowa. Postrzeganie otoczenia międzynarodowego Chin jako czynnika mogącego ułatwić modernizację państwa przekładało się również na sytuację w Cieśninie Tajwańskiej.

częstsze i głębsze kontakty z Tajwańczykami (chociażby poprzez ulokowane głównie tam inwestycje tajwańskie) niż Pekin. Za: B. Y u, op. cit., s. 28. 